\title{
THE AMERICAN KOINE-ORIGIN, RISE, AND PLATEAU STAGE*
}

\author{
J.L. DILLARD
}

\section{University of Puerto Rico}

The early dialect history of the British immigrants to the United States involved a leveling process, leading to the formation of a koiné. Reports from British travelers in the eighteenth century indicate a "striking uniformity" in the English of the American colonists. Comparison with the early reports from Australia, and with general works on the theory of languages in migration, indicates that the development of a koine would be expected in a situation of the type prevailing, where dominant regional patterns of settling in the new country cannot be convincingly shown. Since observers in the late eighteenth century begin to be critical of American usage, it is concluded that the koine stage was drawing to a close by that time and individual American dialects were developing. It is concluded that the formation of those new dialects was traceable to influences other than the regional dialects of more recent immigrants from England.

Marckwardt's (1958) choice of the Mayflower passengers as his example of those who supposedly brought the uncomplicated dialects of England to the North American colonies is an especially unfortunate one. All of the British immigrants to the Americas entered a linguistically complicated situation-although, obviously, not with the same kind of complexity faced later by non-British immigrants-but the Pilgrim Fathers provide an especially obvious example of why the reconstructive picture of British "regional" dialects migrating to North America will not work.

Regionally, the Pilgrims may have been more homogeneous than the generally heterogeneous emigrating British groups. According to historian Charles M. Andrews,

The leading centers of Separatism [the general nonconformist religious movement of which the Puritans were part] were in London and Norfolk, but the seat of the little congregation that eventually led the way across the sea to New England was in Scrooby in Nottinghamshire (1919: 6).

Thus, the Pilgrim group, which was quite small, may at one time have actually represented a "regional" British group with its dialect. But a great deal of complication was to come to that simple picture before the group even set sail for America. And language contact was a major part of that complication.

What is very well known to historians, but apparently forgotten by authorities on American English, is that the Pilgrim group went not directly from England to the Americas but most immediately to Holland. Leaving Britain secretly, they went to Amsterdam in 1607 and 1608 for the express purpose of escaping persecution by the Established Church of England. But they found some flaws with Amsterdam and soon moved on to Leyden-in 1609. Although their early descriptions of the latter city are glowingly enthusiastic, they soon found reason to feel that they should move on. The specific reasons are rather interesting for language history:

1973 copyright by the author 
They were breaking under the great labor and hard fare; they feared to lose their language ... [emphasis added] (Andrews, 1919: 8).

The Pilgrims were also apparently of the opinion that, in the Dutch situation, they had no opportunity to educate their children.

The fear of losing their language may have been a real one. Several writers have commented on the amount of linguistic assimilation which the Pilgrim group underwent, in a comparatively short time, in Holland:

It is curious to notice how these English people became absorbed in the Dutch, so that not only their names have acquired a Dutch form but even their signatures have this Dutch form (Plooij, 1932: 91).

Assimilation to Dutch ways, furthermore, brought increase in the associations with the sea which all the American immigrants had to have to one degree or another. William Macon Coleman reports

Their children were marrying off among the Dutch, and were seeking their fortunes in the four quarters of the globe, wherever Dutch ships sailed. They were making no converts. Their sect was too obscure to attract notice, and it was rapidly losing its identity (Coleman, 1881: 44).

Nothing could be further off the mark than the "overland" migration model for the Pilgrims!

Thus, when the Mayflower

went on alone, bearing one hundred and two passengers, two-thirds of the whole, picked out as worthy and willing to undertake the voyage (Andrews, 1919: 10),

it carried passengers who could hardly have represented the "regional" dialects of England at all-much less in pure form.

What happened to the Puritans, linguistically, in Amsterdam and Leyden could hardly have involved the learning of Maritime Pidgin English. For those who went to sea, the story may have been different, although documents are too scanty to permit any certainty about the situation during this period. What went on, on land, between the English and the Dutch-so that the former "feared to lose their language" -was more nearly hybridization than creolization. But some of their native British language innocence must have been rubbed off. Even before Plymouth Rock, the Pilgrims were veterans of the complex world of language contact.

The limited records which we have from the Pilgrim Fathers reflect neither much Dutch influence nor appreciable British "regional" dialect survival. According to Sydney G. Fisher,

The diaries and letters of colonial native Jerseymen, the pamphlets of the time, and John Woolman's Journal all show a good average education and an excellent use of the English language (1919: 192).

Excellent use of the English language is the kind of phrase which recurs repeatedly in the records of observations of the speech of North American colonists, including, but not limited to, the Pilgrim Fathers. Excellent in this case cannot mean "like a native," since every observer operated in the knowledge that all of them were native speakers of English. It may be 
well to begin examining how a language variety which can attract the adjective excellent may have gone about developing-particularly among people who were not of the elite of England and who may not have had the best of educational opportunities.

It will be necessary, however, to include many groups other than the Pilgrims. For all their symbolic value to American history, the Pilgrim Fathers were neither an especially large group nor an otherwise significant one, as Andrews points out (1919: 19-20). And, even in their own supposed haven from the wicked outside world, they were not alone for long. Nearby-too near for the Pilgrims-soon moved Thomas Morton and his infamous group. Morton, who named himself "Lord of Misrule," perhaps in parody of the properly behaved and ascetic Pilgrims, and who is famous from Nathaniel Hawthorne's "Maypole of Merry Mount," was an annoyance to the Pilgrims, who felt that he introduced an irreligious element into the holy new land. But Morton and his followers may have been more typical of what really came to America than the Pilgrim Fathers whom we piously commemorate on Thanksgiving Day.

That part of the new "American" population which came directly from England-and, as our population is constituted today, it is a definite minority-was in itself diverse and heterogeneous. Although coming to what became the United States for a great variety of reasons (seldom those recognized in the history textbooks of the public schools and often not fully acknowledged by the colonists themselves), they had a great deal in common. They were seldom-almost never, except for a few leaders like William Penn the Younger-of the British upper crust. Many of them fled from-or thought they were fleeing from-religious or political persecution. From the poorer strata of England, in the main, they obviously sought economic opportunity in the so-called New World-an aim which could less reverently be called the desire to make a fast buck. As William Eddis wrote on June 8, 1770,

The colonists are composed of adventurers not only from every district of Great Britain and Ireland but from almost every other European government (Quoted in Read, 1933: 323).

For many of them, particularly for the New Englanders, the maritime trade remained, for a long time, the principal economic element in which they could operate. They were, thus, never beyond maritime influences on language. Furthermore, most of them considered themselves to be in an environment which was more maritime than it actually was. The records of the early explorers are full of excited reports of the discovery of the Pacific Coast a very short distance away from the Atlantic Coast. What they had actually found, of course, was merely another river.

For the early colonists, there is also the very important but often forgotten factor that their associations were strongly with the West Indies. To some degree, the relationship of an individual continental colony to the islands may have been stronger than with another colony. Bernard Bailyn reminds us

The colonization of the American mainland had been part of the same movement of European expansion that led to the peopling of the West Indies, and New England grew up, as it were, in the company of these island dependencies. The Pilgrims at one point had considered settling on the Caribbean Coast of South America (1955: 84). 
Neither were the early New Englanders guiltless in the slave trade for which the West Indies and the Southern states are remembered:

And it was in that year [1643] that the first triangular slave voyage in New England history was made by one of the vessels trading in the Canaries, for she returned via Barbados where she bought tobacco "in exchange for Africoes, which she carried from the Isle of Maio." This voyage introduced New England to the trade in Negroes; but more important was the fact that its success stressed to the merchants the rich possibilities of commerce with the West Indies (Bailyn, 1955: 84).

In the West Indies and elsewhere in the slave trade, the New Englanders would have been exposed to the Pidgin and Creole English of the slave trade.

But for the British-derived colonists, considered somewhat artificially (as they regularly are in histories) as a self-contained unit, apart from immigrants from other countries and the "aboriginal" Indians, the major language contact development was something which could have happened with equal naturalness in a non-maritime environment. It was the leveling of differences between the many British dialects which the early groups brought with them. ${ }^{1}$ This is a quite natural process in the migration of groups which speak the same language. The resultant language variety is called a koine. ${ }^{2}$

The koiné did not develop, obviously, the day the first British colonist set foot on the continent of North America; on the other hand, its beginnings probably trace back to the time before they boarded ship. From the evidence available (some of which is presented below), it would seem probable that the full koine stage was reached in the middle of the eighteenth century. Dialect leveling tendencies were apparent from the first period of the American immigration, however. Exceptional as the Pilgrims may have been in some ways, it should be borne in mind that they hardly arrived in the New World speaking an uncomplicated version of a British "regional" dialect.

A great deal of effort has been expended in order to prove that the early British colonists, particularly those in Massachusetts, brought with them the "regional" forms of England. ${ }^{3}$ In fact, that attempt was assumed to have been successful and has been the basis of dialect history of American English. ${ }^{4}$ It has been widely asserted that the great majority of American immigrants came from the Southeast of England, that-perhaps because of their sheer bulk of numbers-they were dominant over the speakers of other "regional" dialects, and that the kind of dialect diversity which they brought from England formed the basis of subsequent dialect diversity in American English. ${ }^{5}$ It has even been asserted that the Black English Vernacular is attributable to an amalgam of dialect features from areas of England like East Anglia. ${ }^{6}$ Kurath has asserted, however, that virtually all "regional" dialects of British English made the trip to North America, and that all of them are reflected in influences on American English. ${ }^{7}$

The demographic data upon which such suppositions are based are, however, far from conclusive. A work often cited by those of this persuasion, Fiske's The Beginnings of New England provides a confident statement:

While every one of the forty counties of England was represented in the great Puritan exodus, the East Anglian counties contributed to it far more than all the rest. Perhaps it would not be out of the way to say that two-thirds of the American people who can trace their ancestry to New England might follow it back to the East Anglian shires of the mother country ... (1889: 63). 
And Fiske's conclusions provided background for early work like Allen Walker Read's "British Recognition of American Speech in the Eighteenth Century" (1933). More recent studies have not, however, been so certain of this distribution.

Anders Orbeck, ${ }^{8}$ while remaining relatively orthodox insofar as emigration, immigration, and dialect features go, was somewhat less sure of the dominance of "Eastern Anglian counties":

If he [John Fiske, cited immediately above] meant to include in his "Eastern Anglian counties" Essex, Middlesex, and London, as well as Norfolk, Suffolk, Cambridgeshire, Northamptonshire, Bedfordshire, Hertfordshire, it appears that his statement of the origins is more than borne out, for in the above distribution slightly over 71.52 per cent of those who can be traced [emphasis added] are represented as coming from these counties. If Essex, Middlesex, and London, however, are not included in the term, the number that came from "the Eastern Anglian counties" was 47.44 percent (1927: 129).

The stressed [by me] phrase who can be traced is important here, since only a relatively insignificant portion of the original emigrant group can be traced with any confidence to their "homes" in England. Orbeck concluded

On the whole the above tabulation shows a slightly more scattered distribution than Fiske's statement indicates. The center of the exodus was certainly Suffolk, and omitting London the two adjoining counties, Norfolk to the North and Essex to the South, came next (1927: 129).

Paullin and Wright (1932) present data which, on the whole, are not quite so contributory to the usual assumptions as Orbeck's. Although there are shown to be some concentrations in the Southeast, what really emerges from Paullin and Wright is that every county of England was represented in the "exodus."9

Despite the uncertainty of the demographic data, Orbeck continued with what would have been expected in the reconstructive tradition:

Linguistically the tabulation means that we are to look for the roots of eastern Massachusetts speech in the eastern dialects of England (1927: 141).

With this kind of framework, however, Orbeck did not find the expected, even for the limited area of three seventeenth-century towns in Massachusetts:

Altogether it does seem strange that the records, written by men from various parts of England, should reflect a form of speech so uniform in character and so near the standard speech of England (1927: 143).

And he frames a rather hesitant conclusion:

On the other hand early New England speech may reflect the east midland and, to a lesser extent, the southern and southeastern dialects, the main features of which had in the early modern period blended to form the basis of standard London speech (1927: 142). ${ }^{10}$

Such basically inconclusive results-not only timidly stated by the researcher but based upon a sampling procedure which would not inspire confidence in the most optimistic statistician-hardly give strong support to the assumptions of the 
reconstructive tradition, particularly when it is remembered that the researcher was predisposed to find British "regional" origins for American dialect forms. In fact, Orbeck was forced into a provisional consideration which was positively heretical for the dialectology of his time and somewhat later:

Nor is it impossible to think that some of the divergencies enumerated above may reflect not regional but class dialects, some features of which may have passed into regional dialects not too remote from London (1927: 142).

The heretical consideration that the "features" may have come over in social ("class") dialects rather than first being transmitted into "regional" dialects would not have been tolerated in a researcher of Orbeck's time.

Orbeck's findings do not, certainly, justify Kurath's statement:

Spellings gathered from town records and diaries by Orbeck, Simpson, and Gibson [none of these is identified by any kind of bibliographical reference] such as libity for liberty, patchis for purchase, and ort for ought leave no doubt but that as early as 1700 some New Englanders did not pronounce an / $\mathrm{r} /$ after vowels (1971: 105).

Unless really exceptional evidence is available from Simpson and Gibson (who are not identified!), Kurath's statement is not justified. Although Orbeck himself records no forms "without $r$," he does record some cases of

[r] is confused with [I] . . Palmenter, "Parmenter," Cantlebury, "Canterbury," timble, "timber" (1927: 9).

If the first three examples above are taken over-seriously, one could conclude that the speech of the earlier Puritans had been influenced by some foreign language, like Chinese, one or another of the American Indian languages, or some West African language. The $[r] \sim[1]$ interchange will even fit into the Sabir tradition! For objectivity, then, it would be well to point out that Orbeck also records

$$
\text { adbitration, "arbitration" (1927: 9). }
$$

Orbeck's findings do suggest something about a future course of action, although one that was not adopted for quite some time:

The evidence on [British] dialectal attributions is admittedly slender and except for one single point extremely doubtful in character. We must of course exclude such features as had already developed in standard British English of the period, even though they were of dialectal origin to begin with and have since disappeared from standard pronunciation... [emphasis added] (1927: 141).

Although this "one single point" (the Kentish, southern, and southwestern past participle form without - $n$ ) has not survived in any significant way in American English, and although nothing else could be advanced with any kind of confidence even by a pre-committed researcher, it seems well to operate conservatively and to assume that evidence provided by Orbeck and his two shadowy colleagues does indicate that British dialects-perhaps even "regional" dialects-were very slightly represented in Massachusetts speech around 1700. This would mean that almost complete leveling of such British dialectal forms-discussed below-took place some time after 1700 . 
Although emigrant groups from England came in the main from relatively low social strata, they did not transfer class/caste relationships from England. It did not happen that integral groups (the lord of a manor, say, and his peasants) migrated together. The old social order was, then, broken up. Although those who seek to leave a certain social group and a way of life characteristically take along more with them (in out-of-awareness behavior patterns) than they think to the "new" place or circumstances, social conditions of England were not reconstituted in any precise way in the thirteen colonies. Except for professions (one's status in which might be preserved) and other social relationships like membership in the underworld, the social dialects of England would have had as little direct reflection in North America as the "regional" dialects.

These are matters of basic importance in understanding the history of American English dialects. Geographic and social factors are always stated, in the conventional formulations, as the two important factors in dialect distribution, whether diachronically (historically) or synchronically (at one point in time) considered. Geographic factors have been traditionally over-emphasized, although the imbalance is beginning to be corrected now. ${ }^{11}$ When geographic distributions in the United States and in England have been compared and conclusions about migration patterns drawn, ${ }^{12}$ it has all too often been the case that the regional distributions of about 1900 in England (approximately the date of Wright's English Dialect Dictionary) have been taken for the ca. 1600 distributions which would have affected the colonies directly-assuming that regional distributions in the "mother" country affect those distributions in a colony. What modern studies we have tend to suggest that this is not the case. ${ }^{13}$

Professional and religious affiliations were, as a matter of fact, much more likely to have been maintained and to have continued to exert an influence on colonial behavior patterns, including language. Since religious freedom was often the slogan which united a group of immigrants, and since formerly separated and persecuted groups came together in new geographic areas of their own where "religious tolerance" (for themselves, if often not for others) could be practiced, the factor of carryover from religious groups could have been of paramount importance.

There are, as a matter of fact, two important bits of evidence to support the notion of linguistic influence from religious groups. The most obvious example comes from the Quakers:

They gave offense [in England] by refusing to remove their hats in public and by applying to all alike the words"thee" and "thou," a form of address hitherto used only to servants and inferiors (Fisher, 1919: 3).

This influence on the choice of a pronoun of address, although of slight importance linguistically, is much more certainly established than the regional influences which Orbeck tried to show.

The other influence is somewhat more general in its application. The Scottish physician Alexander Hamilton recorded on August 17, 1744,

This humor [i.e., trait] prevails, even among the lower class of people here [Connecticut]. They will talk so pointedly about justification, adoption, regeneration, free grace, reprobation, original sin, and a thousand other such chimerical knick knacks, as if they had done nothing but studied divinity all their life-time. ... to talk this dialect in our parts would be like Greek, Hebrew, or Arabick (Hamilton, 1907: 139). 
In topic as in certain rather superficial grammatical forms Imore precisely, the referents of those forms-a matter of relationship between interlocutors), religious affiliations which were most often made in England affected the speech of the colonies.

But there is no such evidence for the continuity of "regional" dialects; and from general principles of language in migration we would expect the leveling of differences. We can, then, begin to examine some of the early observations of American English in order to test that expectation.

William Eddis, who had naively expected the contrary from such a heterogeneously derived group, wrote on June 8 , 1770,

The language of the immediate descendants of such a promiscuous ancestry is perfectly uniform, and unadulterated; nor has it borrowed any provincial, or national accent, from its British or foreign parentage (in Read, 1933: 323).

Like many other naive observers, Eddis had some strange ideas about language. Like the schoolmarms of a later period, he apparently believed that language had to be implanted from "intelligent" people to "unintelligent" ones. (In like manner, many research projects in the inner cities in the 1960's went awry because they assumed that children-usually conceived of as being "unintelligent"-got their language from allegedly intelligent parents and teachers or not at all.) But, leaving aside his awkward attempts at interpretation and explanation, Eddis (like others of his time) provided information which fits well into an emerging pattern.

Seven years later, the Reverend Jonathan Boucher wrote,

It is still more extraordinary that, in North America, there prevails not only, I believe, the purest pronunciation of the English tongue that is anywhere to be met with, but a perfect uniformity (Maryland Historical Magazine, 1916: 30).

In the same year, Nicholas Creswell wrote,

... they [the inhabitants of the American colonies] in general speak better English than the English do. No County or Colonial dialect is to be distinguished here, except it be the New Englanders, who have a sort of whining cadence that I cannot describe (1924: 271)

Because we know that certain other population groups (like the West African slaves and the North American Indians) were speaking greatly divergent varieties of English, such statements may at first seem puzzling. ${ }^{14}$ But it soon becomes clear that Boucher, Creswell, Eddis and the many others who made similar statements were reporting on the only Americans to whom they had talked and about whom they knew anything-the white descendants of Englishmen and those few other whites who had completed the process of assimilation without difficulty. The more complicated general picture begins to emerge, however, if we consider the observations of a few more wide-ranging commentators.

The Reverend James Adams was a linguistically sophisticated man for his time. His The Pronunciation of the English Language Vindicated from Anomaly and Caprice (1799) embodies a kind of perception about the relationship between 
spelling and the spoken word which was unknown even among professional linguists until a few years ago. ${ }^{15}$ Adams recognized not only the koiné of the British-derived immigrants but also the Creole of the less voluntary "immigrants" from West Africa:

The Anglo-Americans speak English with great classical purity. Dialect in general is there less prevalent, except among the poor slaves (Adams, 1799: 146).

Others, perhaps not so advanced linguistically as Adams, saw the same things:

It is a curious fact, that there is perhaps no one portion of the British empire, in which two or three millions of persons are to be found, who speak their mother-tongue with greater purity, or a truer pronunciation, than the white inhabitants [emphasis added] of the United States (London editor of Ramsay's History of the American Revolution, 1782, quoted in Read, 1933: 324-325).

Not only did this commentator show some awareness of differences in the "colored" population, but he went on to offer an explanation for the "curious" uniformity among the whites:

This was attributed by a penetrating observer [identified by Read as perhaps John Witherspoon whose weekly papers called "The Druid" had appeared in Philadelphia in 1781] to the number of British subjects assembled in America from various quarters, who, in consequence of their intercourse and intermarriages, soon dropped the peculiarities of their several provincial idioms, retaining only what was fundamental and common to them all; a process which the frequency or rather the universality of school-learning in North America, must naturally have assisted (London editor quoted in Read, 1933: 325).

Like many others, this "penetrating observer" attributed to parents and to teachers what children were largely responsible for; but this is so universal a fault that we could hardly have expected anything better from him. ${ }^{16}$ Even modern linguists are much too inclined to look to the home and the schoolroom rather than the playground for language influences.

These early reporters, whatever their limitations as sociolinguists, were not limited in their geographic experience of the colonies. In fact, they characteristically tried to get the overall picture-perhaps because many of them hoped to write a book about the upstart nation-in-the-making when they got back to England. John Harriot, a military man who came to America in 1793, asserted that American English was

. . better spoken by the whole mass of people, from Georgia to Quebec, (an extent of country more than 1200 miles,) than by the bulk of people in the different counties of England (cited in Read, 1933: 325).

As will be noted, the inclusion of Georgia in koine' territory agrees with my overall timetable, in accord with which "Southern dialect" was not yet formed.

The variations from (NB:not in) this American koiné which were being noted were not geographic but social-more specifically ethnic. Many, like Adams and the anonymous London editor, commented overtly on the "dialect" (Plantation Creole or West African Pidgin English, by interpretation) of the West Africa-derived slaves. Others, like John Davis, C.W. Janson, and J.F.D. Smyth, reported relatively long stretches of the speech of Black slaves. ${ }^{17} \mathrm{~A}$ quite large number of others 
quoted American Indians who were very obviously using Pidgin English. ${ }^{18}$ The Reverend Jonathan Boucher also saw some influence from European languages in "some scanty remains of the croaking idioms of the Dutch, still observable near New York."

But aside from the slaves, whom the caste rules prohibited from using the koine even if they ever had an opportunity to learn it, ${ }^{19}$ and some still unassimilated white ethnic groups, ${ }^{20}$ the speakers of English in the North American colonies had achieved the kind of unity which astonished European visitors.

The use of terms like good English and English of great classical purity by the eighteenth-century observers has tended to confuse the issue for language historians. If the standards of the twentieth-century classroom are projected onto the earlier century and the very different situation, good English will be interpreted as involving the "proper" choice in such schoolmarm shibboleths as ain't/aren't/isn't and The game was called due to rain/The game was called because of rain. ${ }^{21}$ Somewhat more advanced schoolmarms, who think in terms of developing their reluctant students into literary figures, may think in terms of the literary dialect-or in terms of some kind of special colonial talent in literary production. Actually, each of these last two is rendered impossible by the circumstances. The American colonists had, as is well known, little access to books and little opportunity to. master the kind of literary dialect which was purveyed in the London coffee houses and received in magazines of the time like the Spectator and the Rambler. While there may have been some cases, like medieval Iceland, of a kind of inherent talent for literary creation in the entire population, the poor colonial literature which has reached us does not attest to any such productive miracle in eighteenth century America. Good obviously means something quite different in this context, and must be interpreted in a different frame of reference.

What the entirety of the statements quoted above does show is that good meant "without recognizable, stereotypable social or geographic features." 22 For the immigrants to North America who had enjoyed the advantages of such liberty as was provided in the new environment, access to the koiné dialect had required just one generation. ${ }^{23}$ Although the American colonists, like the British visitors, had chauvinistically-as adults-chosen to credit the accomplishment to grownups and even to schoolteachers, it had been the children who had actually brought about the situation.

How can uneducated and inexperienced children accomplish in a few years what the most highly trained pedagogues cannot accomplish in decades? Well, mainly by aiming at a practicable result rather than the high-flown impossibilities of the schoolteachers. For a subsidiary explanation, we can point out that the children work on language in an out-of-awareness situation, at play, rather than where obvious attention to language is developing self-consciousness, in the schoolroom. The process has been known for some time, and frequently commented upon:

The explanation [for linguistic assimilation in the United States] is of course the public schools, where the American children americanize the immigrant children in a rough and ready fashion, making life miserable for them if they ever use a foreign word (Dr. George E. Noyes, quoted in Hills, 1929: 432).

In the early days, what children did was to "make life miserable" for any other child who used not just a word but even a pronunciation or syntactic feature which could be observed to be peculiar, individual (in terms of the group norm), or 
unusual. Whatever "regional" or other dialects their parents may have retained when they came to the Americas, the children learned the koine for the best of linguistic reasons-if they did not, they would have to bear the ridicule of their peers.

Nor was this a peculiarity of the colonial situation, of the early United States, or of the melting pot. Given an equivalent mixture of dialects, the koiné-izing process will take place anywhere-as long as there are not insuperable social rules (like caste/class barriers) which forbid its working. The process has been explained, with special reference to French dialects, by the great Indo-Europeanist Meillet:

The fact that French is spoken at the present time in Paris by a majority of provincials and of foreigners is, 1 believe, of great importance. At first sight, the effects are not appreciable, but the fundamental result is that "Parisian" is disappearing, drowned in a sort of Koine (common speech), just as Attic formerly disappeared drowned in the Greek Koine. The idiomatic character of the "Parisian" is being progressively effaced (Quoted in Hills, 1929: 431).

In fact, this koiné-forming process may have taken place a very large number of times in human language history. Although seldom discussed, it probably deserves a much larger place in dialect history than it has ever been accorded.

The American colonies were, at least, not alone in this process insofar as the British migrations were concerned. We find conclusive evidence of the same process in Australia.

As is very well known, the British who emigrated to Australia came from many parts. The importance of the convict population among the early settlers is well known and no doubt exaggerated; responsible historians have pointed out that the "convicts" were often people guilty of no greater crime than being poor and in debt. But the Australian immigrants, like the Americans, were not British upper crust-nor were they from a few areas of England, concentrated together in the new land. Rather, they came from all parts of the mother country. The conditions for a koiné were, then, perfect; and the additional parallel to the North American situation in the use of Pidgin English has been referred to already.

There are reports about the language of the early population of the continent "down under" which parallel those of the thirteen North American colonies. G. L. James wrote, in Shall I Try Australia? (1892), that the English of Australians was

free from any distinguishing accent or provincialisms to a marvelous extent (Quoted in Baker, 1945: 432).

And there are other such statements quoted in J. R. L. B. Bernard (1969). ${ }^{24}$

The Australian koiné was not, obviously, the same one as that utilized in the American colonies. The dialect mix was somewhat different, and the relationship to the maritime varieties was also different; but the most important factor must have been the different group of "Aboriginal" and other languages which were in contact with Australian English, mostly through the medium of Pidgin English. It also does not seem that the great numbers of immigrants who came to the United States from other European countries had any parallel in Australia.

When dialect differences developed in Australia-as they inevitably would, given the complex linguistic situation-they developed in a very interesting distribution. Bernard's article, cited above, describes the lack of "regional" dialects in Australia. As G. W. Turner comments, 
The homogeneity of Australian English is remarkable ... Even if we include New Zealand, differences are hardly more marked that we find with the eastern United States (1966: 163).

Turner's explanation is that

The nomadic life of the rural workers helps to explain the uniformity of Australian speech and idiom (1966: 15).

This may have been true in Australia; but, as we shall see later, the most "nomadic" group of Americans was deeply involved in the change from uniformity to diversity. ${ }^{25}$ Bernard also indicates that he finds no social dialects, in the usual sense of that term. It seems however, that he may have had a narrow definition of social distribution restricted to something like "correlated with class/caste stratification."

Very possibly, if it had not been for the many immigrating European ethnic groups and their influence, the Spanish, French, and other colonizing groups, and certain other language contact factors which cannot be discussed here, American English would have attained a geographic uniformity of dialect distribution about like that of Australia. As it was, however, there were a great many social, economic, and political differences, some of them, like the changing attitudes toward slavery, coming to correlate with region.

Thus, the further development of the American koiné was sui generis, and the comparison to Australian helps little for the understanding of anything except the relatively early American period. There are, however, tantalizing bits of evidence of historical continuity in the contact varieties used in the two English-speaking countries. For example, waddy "cowpoke, cowpuncher," one of the best known terms of Western cattle ranching in the United States, seems to have originated in Australia. (In Pidgin English there, it apparently came from English wood-with the enclitic vowel-but came to have a verbal use parallel semantically to "punching" cattle.) And calaboose "jail," often called a borrowing from Spanish in the Southwestern United States, is reported in use on Manus, a tiny island to the North of New Zealand, by Margaret Mead (1956).

\section{The Nature of the Koine'}

Apart from its uniformity (a redundant statement when the subject is a koiné!), it would be interesting and instructive to know something about the American koiné. There are, however, some barriers to easy knowledge. Whereas foreign observers, especially Englishmen, are all too willing to give specific examples at a later stage when they react to American English as "bad," that usage which they described as "good" just brought the descriptive adjective and almost nothing else. The eighteenth-century British approvers of American English were not nearly so specific as the nineteenth-century disapprovers. The device of internal reconstruction-a kind of very learned, very complicated guesswork-has been rejected for purposes of this study, and for a very basic reason: Internal reconstruction has never allowed for contact varieties like pidgins and koines', which I believe to be of basic importance for the history of English in the United States. 
With the exercise of some ingenuity, however, it may be possible to expand some rather indirect comments on usage into some kind of indication about the vocabulary of the early immigrant.

False blame for innovations which Englishmen often regarded as "corruptions," was often placed on the Americans in later years-particularly in the nineteenth century. In most cases, the complaining Englishmen cited word usages which, they said, no Englishman had ever heard before he listened to the Americans. The Americans, it was concluded all too hastily, must therefore have made up either the stigmatized words or the "new" meanings which had been attached to them. Now, some few of these words about which the Englishmen complained were actual American innovations. But the great majority of them seem to have turned out to be old Britishisms, either obsolete in the British Isles or restricted to non-standard dialects which the literary men who made the complaints did not happen to know.

These words, then, must have been in use in England at some time in the past. (It can, in fact, be shown, in most cases, that they were.) Later, they turned up as Americanisms, which the Americans "naively" took to be good English. These words must have made up at least a part of the vocabulary of the koiné. From general linguistic theory, we can say that the vocabulary of the colonists, like that of any group, was very large; most of it would have been identical, or virtually identical, to the British dialects-the main other varieties of English in existence at the time. But naive observers of language are virtually deaf to similarities and marvelously adept at perceiving differences. They would, therefore, have singled out for comment those words which made up part of the distinctive vocabulary of the koiné.

The vocabulary differences between British English and the Koiné (therefore, early American English) were not the ones which are popularly well known today. Petrol and gasoline, lorry and truck, lift and elevator, chemist's and drugstore-a great number of the easily cited shibboleths-are later developments. One need only consider that there were no automobiles in the eighteenth century to have either bonnets or hoods. Still, whatever we can find out about the koiné vocabulary may be of some use in understanding later changes in American English and further divergences from British English.

Of the condemned "Americanisms" which turn out to be British in origin after all, some have completely disappeared from the language-except, of course, as they may be met with by students of earlier literature. Of the words for the use of which David Hume criticized Benjamin Franklin in the latter part of the eighteenth century, pejorate fits into this category, whereas colonize and unshakeable are so familiar today that we cannot imagine how anyone could object to them. They have apparently been reabsorbed into British usage and the stigmata removed from them-which is one of the major relationships between British and American English cited by those who disbelieve Mencken's thesis about a separate "American Language."

Of course, pejorate is related to pejorative, a term which is in everyday academic usage, if perhaps not to be heard constantly on Main Street of every town in the country. And the linguist is forever talking about pejoration (the opposite of amelioration) in historical semantics. Almost all of the distinctive koiné words have cognates (historically related forms) in present-day English vocabulary, and the student who encounters one of them in an eighteenth-century text is not likely to be puzzled about them for long. But, if he is observant about his own usage, he will realize that he has never used them in that way and probably never will.

The words of this type which can be isolated are a heterogeneous group-some as staid as pejorate but others as racy as bamboozle. Psychologizing is strictly out of order here: We cannot say anything much about the vocabulary and early 
American character, whether taking the words as cause or as effect. Some which are slang today probably were not in the eighteenth century. But, historically, there is one common trait which most of them seem to have: None of them was widely used in the American multilingual contact variety, Pidgin English. One possible exception is swap, which may actually have been transmitted through the pidgin and not the koiné.

A partial list of such words follows:

\begin{tabular}{ll} 
bamboozle & guess ('suppose, opine') \\
banter & illy \\
belittle & influential \\
boatable ('navigable') & immigration \\
budge & loan \\
calculate ('suppose') & lynch \\
carry on ('raise a pother') & memorialize \\
chaperon & notify ('inform') \\
cleared & portage \\
clever (one meaning of) & progress (verb) \\
coax & reckon ('suppose, opine') \\
collide & row ('a disturbance') \\
creek (one meaning of) & spur \\
derange (verb) & square ('a small city park') \\
enterprise (verb) & statehouse \\
expect ('think, suppose') & stingy \\
extinguishment ('extinction') & suppose \\
fall (time of year) & swap \\
feaze (verb) & swimmingly \\
fellow countrymen ('countrymen') & talented \\
fib & touchy \\
fop & upland \\
fun & vended \\
gap & wobble \\
\hline &
\end{tabular}

A look at the dates of occurrence, in England and in America, for several of these in the Oxford English Dictionary (OED) provides some interesting insights into the vocabulary of the colonies and the early United States. Of square 'a small city park' [NB: NOT square "what you can't do to the circle," or square "unhip"] Mencken says

... not an Americanism. The DAE [Dictionary of American English] traces it to 1698 in Philadelphia, but the NED [or OED] finds an English example eleven years older (1945: 118).

Bamboozle, which looks so American that it was automatically attacked by many commentators, "was under fire before [Samuel] Johnson attacked it [in his dictionary]," and it was used by Colley Cibber in 1702 and attacked by Jonathan Swift in 1710. Budge was

old in English, and was in good usage until the seventeenth century, but for some reason the purists of the eighteenth century took a dislike to it (1945: 156). 
The word was listed as slang in F. Grose's Classical Dictionary of the Vulgar Tongue (1785).

Analogous statements can be made about most or all of the words listed above. In most cases, however, the first recorded American usage is somewhat later than 1698; the dictionary-listed forms tend to cluster between 1720 and 1730 . It may, then, be a fair working hypothesis to say that the koine' was being formed slightly before 1700, that it was in its hayday around 1730 (dictionaries, which depend on written usage, always reflecting the situation of a few years earlier), and that its partial decline began around 1780 , when other influences from the complex multilingual situation in the United States began to make themselves felt so as to be no longer capable of being ignored.

The reader will please remember, however, that this "decline" of the koine' was a relative matter. The results of the koiné-forming influences are still felt in the prestige accorded to a relatively unmarked dialect and even in insistence upon it for certain domains of usage.

\section{Threats to the Koiné}

Although to some degree an artifact of analysis, the notion of complete separation of the koine and of the contact varieties is an expedient one for temporary purposes. (Something of the same sort is done everyday, when an ordinary speaker treats "slang" as though it were apart from other features of the same language). If we can trust travelers' reports and subjective reports on the part of American speakers, the "pure" koiné was achieved fairly early in the eighteenth century and it began to "fade" in the latter part of the eighteenth century. As will be seen below, I do not believe that the complete "destruction" of the koiné ever took place. Efforts to maintain it-often mistaken, even by those making the effort, to be something else, like preserving "good" English or encouraging literary creativity-continue, with a certain amount of success, to the present time. For the present, the most pressing issue is that of the factors which threatened it.

Almost paradoxically, purism is one of the greater threats to the leveled dialect. Especially those who looked to outside models-in this case, specifically, British English - would be seeking to remold the koiné on some other pattern, which would mean, in effect, changing it into something else. Those who sought to remake the language according to their own, rather naive ideas of "universal logic" ("two negatives make a positive") are to some (superficial) degree meddling with the natural process of leveling. So is the prescriptivist who tries to impose some simplistic etymological constraint on language forms (e.g., arrive comes ultimately from Latin ad ripam 'to the bank'; therefore, one cannot use the English verb to mean 'reach the middle of a stream").

Every department of English or of Linguistics has probably received at least one call from a local radio station or local media agency frantically asking for advice on a "technical" question of grammar like

Is it really correct to say you are? Wouldn't it be better to say you is, when you mean only one person?"

This inquirer has been thinking too much about grammar, just as the problem of many a stutterer is that he thinks too much about what he's going to say, or how well he's going to say it. Inquirers like these-and the people, whoever they are, who 
apparently do buy those newspaper-advertised courses on how to "improve" one's English-contribute, to some small degree, to an influence upon language which is opposite to that of the leveling process.

For the insecure, even in fairly early times, the outside influence sought was British usage. And there were, almost from the beginning. Anglophiles and others who sought approval and "correction" of American usage from Britain. They seem to have had an occasional bit of influence.

The French avenue ... had been used in English for some time. But . . no American had Avenue as his address until the founding of Washington. Even the later popularity of Avenue may be partially credited to New York (Stewart, quoted in Marckwardt, 1958: 164-165).

British influence was always stronger on the eastern seaboard; and New York was never a real locus of the koine or of the post-koiné standard. Other examples of direct Anglophilic influence may perhaps be found in the adoption of the British 'r-less' pronunciations in post-vocalic position (in card, yard, car, far, etc.) in certain cities. (See Labov, Sociolinguistic Patterns, 1972: 64).

But Anglophiles and usage-worriers are operating at the within-awareness level of language, where not much happens anyway. There were more serious competitors to the koine' in the other language varieties in which North America abounded. And the agents of the challenge to the leveled dialect were the same ones who had been originally responsible for it-the children. The obvious speakers of the foreign languages, pidgin and creole varieties, and "accented" were the non-British and non-assimilated minority groups. They tended to have ready access to the children, if not the adults, of the British-derived population. Like Europeans in Africa, South America, and Asia today, the First Families of Massachusetts and Virginia could not resist the temptation of cheap baby sitters. $A$ result was that

In this strong basket, fashioned by an Indian mother, many a white child has been swung and sung to sleep (Earle, 1899: 21).

It is not known, apparently, how many colonial children grew up speaking the Indian languages, but, from what we know of other situations, we can be quite sure that more colonists grew up bilingual from childhood than ever became so from conscious study as adults.

In the American South and in the West Indies, being cared for by a Creole-speaking "Mammy" was the superficial part of learning English Creole, insofar as the white child of a slave owner was concerned. More importantly, "Mammy" had children who were brought along to play with "Young Massa" while Mammy did the work; and there was the institution of play children from the slave population on the big plantations. (Primarily, it was a way of getting some return out of the slave children before they were big enough to work profitably in the fields; but it gave an unexpected lagniappe linguistically.) This situation is discussed in some detail in my Black English (Chapter V).

But the strongest and most effective threat to the koine came in the myriad language contact situations on the frontier. The hunters, miners, trappers, and scouts who went out beyond the "civilized" area and dealt with people who were, by and large, not native speakers of English, were no longer in a dialect-leveling or a dialect-maintenance situation. Influence from 
this very different type of contact situation was the greatest influence on the fading of the koine, especially insofar as the common man was concerned. [Linguists who may have read this far will please read on before jumping to the conclusion that I have committed myself to a "substratum" explanation!] With the proliferation of those conditions, the koine came to be more and more relegated to the media, the pulpit, and the schools-and there it was confused, sometimes fatally, with Anglophilism and the school teacher's notion of "good" English.

\section{End of the Koiné-Dominant Period}

If the eighteenth-century English travelers marveled at the "astonishing uniformity" and "great classical purity" of the English of the Americans, the ninteenth-century traveler was full of no such praise. ${ }^{26} \mathrm{He}$ tended, rather, to be like Thomas Hamilton, who wrote

Though the schoolmaster has long exercised his vocation in these states, the fruit of his labours is but little apparent in the language of his pupils. The amount of bad grammar in circulation is very great; that of barbarisms enormous. Of course, 1 do not now speak of the operative class, whose massacre of their mother tongue, however inhuman, could excite no astonishment; but I allude to the great body of lawyers and traders; the men who crowd the exchanges and the hotels, who are to be heard speaking in the courts, and are selected by their fellow-officials to fill high and responsible offices ... (1833: 127). ${ }^{27}$

A host of other writers joined in that condemnation, like Charles Dickens (American Notes and the American scenes in Martin Chuzzlewit). John Witherspoon, a transplanted Briton who was president of Princeton and author of "The Druid," a column in the Pennsylvania Journal and Weekly Advertiser (Philadelphia), sounded the alarm as early as 1781, although many of his criticisms of current American usage were puristic and pedantic, and some of them may have been individual "performance errors." The romance between American speakers and British observers was over by the late eighteenth century; and the type of condemnation being met was not simply objection to "innovation" or to the really English-bred (but unrecognized) vocabulary of the koiné.

The Americans themselves regarded the frontier as the special locus of "bad" English. We have statements like that of (later, General) Ethan Allen Hitchcock, A Traveller in Indian Territory (1930: 158) lending his authority as an experienced nineteenth-century frontier traveler to his judgment of the "prominent defects among our border people, West and South" in language. It was in just those areas, because of the multilingual contact conditions prevailing, that the pidgin contact varieties were in use. Hitchcock himself related incidents in which Blacks and Indians used Pidgin or Creole English. He also recorded the case of a Mr. Foreman, a Cherokee, engaged in translating the Bible into English (1930: 51). This gentleman, not further discussed except that his "pure English" was "free from border defects," must undoubtedly have been one of the more fortunate results of the generally inefficient attempts to educate Indians in English.

Like Hitchcock, Albert D. Richardson, author of Beyond the Mississippi (1867), heard "bad" English in the less thickly populated areas. He wrote 
In Kansas [about 1858] one heard the slang and provincialisms of every sector of the country, beside some indigenous to the soil (1867: 132).

A more finicky dialectologist than Richardson would say, of course, that, since the slang and provincialisms "of every sector" were heard in Kansas, they were not really peculiar to those sectors-that they "belonged" to speech communities and not to regions. But the thrust of the observation by Richardson, whose book is also a good source for Pidgin and Creole English use in the American West, is clear enough.

John G. Bourke (On the Border with Crook) was explicit about the English of Arizona when that state was characteristically frontier:

While the language of conversation [at a dance] was entirely Spanish, the figures were called off in English, or what passed for English in those days in Arizona:

\author{
"Ally man let ' $n$ ' shassay;" \\ "Bal'nce to 'yer podners ' $n$ ' all han's roun" " \\ “Dozy dozy-chaat 'n' swing" (1891: 89).
}

Although no one seems to have thought of putting them all together before, comments from all frontier sections tend to agree in this particular. In 1866, Colonel R. B. Marcy wrote of the Southwest,

The people inhabiting the rural districts of the Southwestern states have . . adopted many words and phrases which are not found in Webster's Dictionary or sanctioned by any of our grammarians. They have also taken the liberty of changing the pronunciation of many words in such a manner, and applying them in such novel ways, that it is almost impossible for one not familiar with these peculiarities to comprehend their meaning in ordinary conversation (1866: 383).

Marcy, like other amateur observers, was better at recording his impressions than he was at detailing what made up "these peculiarities." In this context, he gives only a few pronunciations (1866: 383):

$\begin{array}{lll}\text {... they call } & \text { bear } & \text { bar } \\ \text { door } & \text { do } \\ \text { chair } & \text { char } \\ \text { stair } & \text { star } \\ \text { crop } & \text { crap }\end{array}$

Marcy also quotes a number of the frontier residents to whom he talked. One of them, Black Beaver la Delaware Indian Interpreter who had moved in from the Northwest) spoke American Indian Pidgin English. One Negro woman spoke differently from other persons of the same area (1866: 377), a partly decreolized version of Plantation Creole. But the frontier whites had, according to Marcy's evidence, a distinctly non-standard dialect of their own. ${ }^{27 a}$

During the same period, similar reports were coming from all parts of the frontier. Of Salt Lake City, world traveler Sir 
Richard Francis Burton (The Look of the West), who later, at least, heard Krio in Sierra Leone, was astonished at what he heard in the Utah capital:

... every word was apparently English, but so perverted, misused, and mangled, that the home reader would hardly have distinguished it from high Dutch: e.g., "Im intire made as a meat axe; now du don't, I tell ye; say you, shut up in a winkin, or l'll be chawed" (1860: 207).

It seems clear, however, that what was developing on the frontier was not a group of "regional" patois of the type familiar from Europe. 28 Rather, the varying groups of the frontier tended to develop trade and professional registers ("slang" or "jargon") which were strange to outsiders. These particular in-groups might develop usages which ranged over wide areas, always being basically kept from outsiders. Of the Northwestern trappers, E. N. Dick wrote,

... they developed a spoken language which was so interspersed with idioms that it was difficult for the uninitiated to understand (1941: 69).

The trappers, like others who had left "civilization" far behind, were exposed to and picked up many new modes of communication. Some of them seemed positively non-verbal, in the narrower sense of the term, although they were fully users of symbolic and linguistic systems:

The Indians had a universal sign language by which members of the different tribes who could not understand each other's speech could converse readily for hours. Often by way of practice trappers sat conversing by this method, and it was reflected in the sparsity of words of their conversation (Dick, 1941: 69).

The taciturnity of trappers, the familiar point of many a stale joke, ${ }^{29}$ apparently had some historical basis. But, in addition to sign language, the trappers undoubtedly learned Pidgin English, for a time one of its major competitors as the frontier lingua franca.

The use of Pidgin English by Indians is attested, in fact, from Maine to Georgia, and from the East Coast to Oregon. Its use by Indians began long before the nineteenth century; but its spread to the sign language-using Plains Indians was greatly facilitated by the pushing westward of the coastal tribes, who did not understand the sign language.

And there were other groups who used varieties of English which had never undergone the specific type of leveling of the koiné but had developed by a different process. There was, for example, the Black population, a great portion of which spoke the Creole ancestor of Black English Vernacular (see Black English, Chapter III). Although our western novels and motion pictures have peopled the frontier with men who looked like John Wayne and Gregory Peck, they were really just as likely to be dark-skinned as pure Anglo-Saxon. There were, as has been proved, many Black cowboys. ${ }^{30}$ Blacks were in the "wild" frontier areas from very early times, as runaways to the Indians or as slaves (who were often in virtual control of their titular "masters") to the Indians. And their Plantation Creole went along with them. Julian Mason shows how the African word buckra rather quickly got as far as Oregon (1960).

The near-standard English of the house servants, largely decreolized, turned up among those Blacks who were 
transported under white auspices. Richardson records a servant woman who has been trying to prospect for gold and who answers her master's queries about the rocks she carries with

Speciments, mass'r, speciments!(1867: 488).

Somewhat further east (Alton, Illinois), painter George Catlin got, from "a black boy belonging to my friend Captain Wharton" the even more Fancy Talkish: ${ }^{1}$

My good massa, massa Wharton, in dese house, jist dead ob de libber compliment (Catlin, 1856: 93).

Chinese were also all over the frontier after the Gold Rush immigration beginning in $1849 .^{32}$ As Rusling (Across America) reported of Portland, Oregon,

John Chinaman turned up again (1875: 268).

Rusling was amazed at the behavioral Americanization of the Chinese, in spite of their lack of linguistic assimilation:

They engaged in all household duties, ran errands, worked as traders, performed all kinds of manual labor, and yet as a rule their only dialect was a sort of chow-chow of "Pigeon English" (1875: 299).

Richardson, like many other commentators and observers, also reported about the Chinese and their variety of English:

Their chief deity is called "Josh." In a violent quarrel between a Chinaman and a Jew, the former wrathfully said, “Oh, yesee; I knowee you-you killee Melican man's Josh" (1867: 239).

The astonishing assimilative powers of the Chinese in American ways apparently included even anti-Semitism, and all in Pidgin English!

From the Pacific Coast to rural East Texas, some Americans learned the condiment chow chow and its name, the ultimate source being Pidgin English-speaking Chinese. Their joss houses (sometimes called josh houses) are still visited by tourists in San Francisco, New York, and (probably) several cities between. In the Northwest, loggers and other groups dealt with the special contact variety called Chinook Jargon and picked up some of its vocabulary. All in all, hardly an American group remained uninfluenced by one or the other of the contact varieties.

\section{The Maintenance of the Koine'}

Statements as to the uniformity of American English being rare by the end of the eighteenth century, and indeed overt statements to the contrary becoming commonplace along about that time, it seems inescapable that the "pure" koiné situation flourished in the eighteenth century and was gone by the end of that period. (Since this is, coincidentally, the time of a lot of neo-classical theorizing about "correctness" in language, the evidences of the koiné have largely been confused with and mistaken for that phenomenon.) But recognition of diversity was not approval-quite the opposite in fact. Attempts 
to eliminate variation and to restore uniformity (whether or not motivated by eighteenth-century grammatical theory) tended to center, always, around certain institutions: the schools, the church, and the early media. Of these, only the schools have been given any great deal of attention, since they were the early seat of the purism which the linguists of the twentieth century have hated and attacked incessantly.

The early schoolmarm (whether male or female) was obviously endowed with more prescriptivism than linguistic knowledge. It is commonplace that he (or she) was sanctimonious in his/her mastery of "good" English and scornful of the "ignorant" variation of the pupils in the schools. (This is, as everybody now knows, a very poor foundation upon which to build successful language teaching.) And the schoolmarm/master frequently confused her/his task of maintaining uniformity (or, even better, of teaching the students a dialect lingua franca) with that of expunging "bad" English. All too often, the "correct" variety toward which the teacher yearned was not any American variety-or any variety mastered by the teacher-but British English (sometimes even "Oxford" English!), for which there were no real models around. Not really cognizant of British pronunciation, the poor schoolmarm too often simply insisted that the pupils "pronounce all the letters"-a failing of pedants which, on the evidence of Shakespeare's Holofernes, must go back a very long way.

Too often, also, the rules of the school grammars were based upon Latinizing or pseudo-logical considerations ("Two negatives make a positive"). "Rational grammar" has a respectable linguistic status, 33 but hardly in the common schoolmarm's meaning of the term.

But the positive force of schoolmarmism should not be entirely overlooked. Mixed in, almost haphazardly, with the morality about language and the desire to achieve unrealistic and unachievable models, was a drive toward "universal intelligibility." In its better manifestations, this drive approached the very sensible ambition of having a dialect taught to all speakers which would be usable in all situations.

Even in the twentieth century, those supreme repositories of purism, the Freshman English handbooks, have aimed at an English which was

\author{
Reputable \\ National \\ Current $^{34}$
}

The first probably represents a desire to avoid those "shocking" four-letter taboo words which all of us know but few dare use in public. The second militated in some degree against the development (or use) of localisms-and thereby earned the undying enmity of the Americam Dialect Society. The third was an injunction against using the older varieties of English-Old, Middle, and Elizabethan, etc. (although the same schoolmarmism insisted that the students should study that which they were not allowed to use).

But the major factor in the maintenance of the "common" dialect has been the internalized attitudes of American speakers. Even the dialect geographers have been forced to give sporadic recognition to those attitudes. Atwood acknowledged 
Gillieron's method of merely asking an informant to translate a term into his dialect would have little value in the United States, since no one wants to admit that he speaks a dialect (1963: 11).

There was a kind of generalized feeling that American English was "its own thing" and that there was one relatively uniform variety which had special ("standard") function. Each of these attitudes was reflected-NOT created by-teachers and textbook writers, including the interesting but over-rated Noah Webster, for his historical importance. The speech community itself took care-quietly and efficiently-of the tasks which the pedagogue and the grammarian were frantically declaiming about.

When the very different needs of the frontier promoted diversity rather than uniformity in American English over its entire geographic extent, the uniform dialect was not completely forgotten. Schoolteachers came among the frontier children and performed their task, however awkwardly they might conceive of it. Speakers of American Standard came from the East to lecture and entertain them, in series like the Lyceum ${ }^{35}$ and the Chautauqua. ${ }^{36}$ Soon, widely circulated books and magazines came to give written models of the uniform dialect. By the time of the invention and widespread use of radio, it was a commonplace that radio announcers must speak "good" English and that only comedians could use dialect. (After the famous test case of Dizzy Dean in St. Louis, sportscasters were given essentially the same dispensation as comedians.) By the time of network television, these norms had been so thoroughly established and accepted that linguists now speak with confidence of Network Standard. ${ }^{37}$

So, the American koiné is hardly a "dead" language. It has managed, remarkably well, to adjust to the times and to adapt itself to new situations and demands. Especially if the schools will remove their kiss-of-death labeling of it as "good" English and utilize it for what it is, the uniform dialect has as bright a future as any other speech variety of mankind.

\section{Footnotes}

*The materials contained herein will be published, in slightly different form, in Professor Dillard's forthcoming book, tentatively entitled A History of American English, to be published by Random House, Inc., in 1974. All rights reserved by the author.

${ }^{1}$ The basic principle of leveling in the American colonial dialects was well established in Allen Walker Read's "British Recognition of American Speech in the Eighteenth Century," Dialect Notes, 1933. Read did not, however, use the term koiné. In a later article ("The Assimilation of the Speech of British Immigrants in Colonial America," Journal of English and Germanic Philology, 1938), Read subscribed to the notion, then becoming popular, that the southeastern counties of England-the area around London-had given its basic character to American English. It is occasionally hinted at, but never apparently treated in detail, that the "London" dialect was itself the result of a leveling process. Although it is beyond the scope of this paper, there is considerable reason to believe that this kind of koiné-forming process goes well back into English language history. In the Middle English period, and in the Renaissance, there were frequent statements about the ridiculing, at court, of speakers of a noticeable dialect. After discarding the literateur's notion that Chaucer had invented a prestige Middle English dialect, historians generally gravitated to the position that it was the "regional" dialect of London. The possibility that the court (like later stage, radio, and television broadcast networks) was the locus of the standard dialect would be, however, one worth investigating. If that is the case, of course, the standard dialect can hardly be called "regional" in any meaningful sense of the term. 
${ }^{2}$ The most important recent treatments of koiné-formation in specific situations are Haim Blanc, "The Israeli Koine as an Emerging National Standard," and Nida and Fehdereau, "Indigenous Pidgins and Koines," International Journal of American Linguistics, 1971. The latter treats pidgins, as well as koinés, as "internal" developments, in individual contact situations. While agreeing with Nida and Fehdereau that pidgin-using and koinéforming situations are strongly analogous, 1 cannot agree that the "Sabir Pidgins" at least are special formations. They were, rather, transmitted by maritime routes and in some frontier situations.

The Old English migration (traditionally around 449) to England apparently did not engender this kind of leveling. From such traditional sources as we have-and they are far from the actual date of the reported migration-a possible explanation appears. It would appear that the "Anglo-Saxon" migration was more or less tribal in nature. The American migration was not.

${ }^{3}$ The motivating philosophy behind these attempts was a noble, politically liberal attitude. It is typically represented by a statement in Hans Kurath's "The Linguistic Atlas of the United States and Canada," in D. B. Fry and Daniel Jones (eds.), Proceedings of the Second International Conference of Phonetic Sciences,

... folk speech and cultivated speech are very close together in recently settled and democratically organized America (1936: 19).

While one must of necessity feel almost guilty about criticizing a statement of such high seriousness and noble innocence, it must be immediately apparent to any reader that neither sociology nor dialectology could possibly proceed in any objective terms without at least leaving such a statement open to question. In fact, it was the recognition of the inadequacy of a dialectology based on such virtually gullible preconceptions which led me first to develop an interest in social dialectology. And it is very tempting to quote one of my brighter students, who, after I had just pointed out that the phrase recent/y settled left out the American Indians, asserted "And the phrase democratically organized leaves out the rest of us!"

${ }^{4}$ According to Kurath ("The Origin of Dialectal Differences in Spoken American English," Modern Philology, 1928), a long tradition of writers who held such preconceptions preceded Kurath himself and George Philip Krapp (The English Language in America, 1925):

It is generally assumed-if one may judge by the statements that appeared in print before the publication of Krapp's work-that American English, apparently also in its spoken form, is essentially the Southern English Standard of the Seventeenth and Eighteenth centuries as modified locally in the course of the last century or two. This is the view advanced by Whitney [Language and the Study of Language, 1868, pp. 171ff], presumably for American English as a whole; by Ellis [J. A. Ellis, Early English Pronunciaton, V, 236] for "the eastern United States, New York and Massachusetts;" accepted by Emerson [O. F. Emerson, "The Ithaca Dialect," Dialect Notes, I, 169-173] for the speech of Ithaca, New York; and defended by Sheldon [F. S. Sheldon, "What is a Dialect?" Dialect Notes, 1, 293] (1928).

Viewed in the context of combatting earlier notions that Americans had "corrupted" the English language and of the struggle for legitimacy of American English, the work of Kurath, Krapp, and even Whitney, Ellis, Emerson, and Sheldon has a great deal that is praiseworthy about it. The trouble is that Kurath, especially, exerted so strong an influence on subsequent dialect research that not only his principles but the details of his presentation hardened into dogma. While leaders and innovators, for their day, in studying the process of change in American English, Kurath and Krapp strangely overlooked all the evidence for the contact varieties, like pidgins. Indeed, they went so far as to assert that such evidence was false. Krapp, for example, excoriated James Fenimore Cooper for not presenting evidence of a "frontier lingua franca," in the midst of quotations from Cooper in Pidgin English (not recognized, evidently, or at least not labeled as such, by Krapp). The result has been that work in one area of study of the American developments has been not just inhibited but virtually tabooed. 
${ }^{5}$ The strongest claim of this sort was presented by Kurath, "The Origin of Dialectal Differences in Spoken American English" (Modern Philology, XXV, 1928). Reluctance to criticize an article of that ancient a date is partly alleviated by the iteration of the same position in Kurath's 1965 article, "Some Aspects of Atlantic Seaboard English Considered in Their Connection with British English." Both of these were reprinted in Williamson and Burke (eds.), A Various Language: Perspectives on American Dialects (1971), a collection which is so narrow in its discipleship to the Kurath position as to make the term Perspectives in the title a misnomer. See my review in Caribbean Studies (1972).

${ }^{6}$ Raven I. McDavid, Jr., "Historical, Regional, and Social Variations," Journal of English Linguistics (1967). See my criticism in "American Negro Dialects: Convergence or Divergence?" Florida FL Reporter (1968; reprinted as "Negro Nonstandard Dialects: Convergence or Divergence?" in Whitten and Szwed, Afro-American Anthropology: Contemporary Perspectives, 1970).

${ }^{7}$ The statement is

Features of pronunciation now more widely current in rural areas than in the great population centers derive either from British folk speech or from earlier stages of SBE [Standard British English] (1971: 107).

Although the term folk speech is ambiguous enough, considered in isolation, to make it include possible maritime varieties, the article as a whole makes it clear that Kurath referred to British "regional" varieties.

${ }^{8}$ The caveats of Orbeck against uncritical acceptance of British dialect origin for American forms are almost as frequent-and, in retrospect, more important-than the statement (and the slight bit of evidence) which he offers in support of such derivations. Consider, for example

The only piece of evidence about which there can be little doubt is the characteristically Kentish, southern, and southwestern past participial form. On the other hand, there are no examples of the southern development of $O E$, i.e. .., no forms indicating the characteristic southern voicing of final $f$ and $s$, no clear examples of western $u$, and the few forms that can be explained as reflecting Kentish e (from OE $\bar{y}$ ) can also be otherwise explained (1927: 142).

or

Some few features may possibly be of [British] dialectal origin, but they are at present so widely current that it is altogether impossible to determine which dialect is to be credited with them. There are isolated forms here and there which may be explained on the basis of the northern dialects. On the other hand it should be pointed out that there are no examples in the records of the northern plural. Nor is there much evidence for the typical Scotch scribal habit of representing vowel length by orthographic $i$ (1927: 141-142).

or

The northern sall for shall occurs in Bradford's History of Plymouth; Bradford himself, however, came from southern Yorkshire within the provenience of the midland dialect (1927: 141).

All in all, Orbeck presents very little evidence for the representation of British "regional" dialects, in any meaningful way, in the early town records of Massachusetts. In the context of defending the legitimacy of American English-and of linguistic change-Orbeck and others like him may be considered praiseworthy. Our respect for them should not, however, go so far as to commit ourselves to their rather shaky (and, in the case of Orbeck, reluctantly drawn) specific conclusions about the British provenience of American dialect forms. 
${ }^{9}$ Charles O. Paullin and John K. Wright, Atlas of the Historical Geography of the United States, Washington: Carnegie Institution, 1932, Plate 70, C and D.

${ }^{10}$ The rather obvious sociolinguistic conclusion to be drawn from such statements is, of course, that the London dialect lor that London dialect usually associated with standard English) is in fact the result of a koiné-forming process of its own. The battle for legitimacy of American English might more profitably, then, have concerned itself with the right of Americans to form a standard dialect in the same way as did the British.

${ }^{11}$ Recent studies emphasize ethnic group loyalties, social stratification, and relationships within the peer group as influences upon each individual's choice of a range of linguistic variants open to him. Certain works of William Labov (The Social Stratification of English in New York City, 1966; Language in the Inner City, 1972a; and "The Linguistic Consequences of Being a Lame," Language in Society, Vol. 2, No. 1, 1973) are representative of the change in emphasis. Social stratification, especially, as a factor in dialect variation was given an early, convincing demonstration by John Gumperz, "Dialect Differences and Social Stratification in a North Indian Village," American Anthropologist (1958). Ethnic group variation is effectively demonstrated in Haim Blanc, Communal Dialects of Baghdad Arabic (1954).

${ }^{12}$ A caveat against uncritical acceptance of such procedures was entered by W. Nelson Francis, "Some Dialectal Verb Forms in England," Orbis, 1961. In one of the closest approaches to the description of the koine ever accomplished by a conventional dialectologist, Francis hypothesized that the Atlantic seaboard regions had probably been "dialectal melting pots" (1961: 8). Although Francis did not say so, this would in the Atlas tradition preclude significant representation of British dialects in the United States, since that tradition assumes that dialects further west represent migration patterns from the Eastern seaboard.

${ }^{13}$ One of the most interesting and relevant studies is that of Werner F. Leopold, "The Decline of German Dialects," Word (1959). In the case of East German refugees subject to dialect pressures in West Germany, Leopold shows that considerable "disappearance" of dialect differences (herein it would be called leveling) can take place even within the adult generation which has migrated.

${ }^{14}$ For some of the records of West African Pidgin English, see William A. Stewart, "Sociolinguistic Factors in the History of American Negro Dialects" (1967), and "Continuity and Change in American Negro Dialects" (1968); Dillard, Black English (1972). For American Indian Pidgin English, see Douglas Leechman and Robert A. Hall, Jr., "American Indian Pidgin English: Attestations and Grammatical Peculiarities," American Speech (1955); Mary Rita Miller, "Attestations of American Indian Pidgin English in Fiction and Non-Fiction," American Speech (1967); and Dillard, Black English, Chapter IV.

15 In a manner crudely prefiguring Chomsky and Halle, The Sound Pattern of English (1968), Adams pointed out that inconsistencies between English spelling and pronunciation (from his point of veiw, apparent deficiencies in the latter) reflected underlying consistency. For example, he pointed out what would now be called a derivational relationship between (e.g.) bile and bilious, and accounted for the different vowel pronunciations in terms of that relationship. While this is hardly of the level of sophistication of Chomsky and Halle, it does represent an awareness of a relationship which some professional linguists of the mid-twentieth century ignored.

${ }^{16}$ For a specific statement on parent-peer influences, see Labov (1972b): 304-307.

17 John Davis, Travels of Four Years and a Half in the United States of America During 1798, 1799, 1800, 1801, and 1802, New York (1909); Charles William Janson, Stranger in America, London (1807); J. F. D. Smyth, A Tour of the United States of America, London (1784). There are, of course, very many other such sources. 
${ }^{18}$ Thomas Woodward, who quoted a rather long passage in Pidgin English from an Indian (Woodward's Reminiscences of the Creek or Muscogee Indians (1859) felt obligated to give an explanation:

Now the above is an Indian speech, and no doubt will appear silly to some who have not been accustomed to these people. Should it, however, fall under the eye of those who were along at the time, they will recognize John's speech, and call to mind our old friends (1859: 70 ).

${ }^{19}$ For a specific application of caste rules to dialect, and some interesting and important generalizations, see John Gumperz, "Dialect and Social Stratification," American Anthropologist (1958).

${ }^{20}$ Still partly unassimilated ethnic groups, besides the Blacks, include the Cajuns of Louisiana, the Pennsylvania Germans ("Dutch"), and the Chicanos. It is, of course, commonplace that some Americans regard themselves as over-assimilated, or as being in danger of losing valuable cultural heritage. Linguistically, such effects are perhaps best known in terms of such activities as the attempts of Jewish Americans to preserve Yiddish. See, especially, the works of Joshua Fishman.

${ }^{2}$ Although some Americans, including many in public life, tend to regard the schoolmarm as a legitimate watchdog of English usage, it is the position maintained herein that Standard English is little affected by-and only distantly related to-schoolmarm purism.

${ }^{2}$ One of the better general treatments of language standardization is Paul Garvin, The Standard Language Question. Language standardization and dialect standardization are of course merely different aspects of the same process. Although Americans have tended to hedge on the matter, Englishmen have been more realistic in judging a "standard" dialect to be free of prominent, stereotypable variations either geographically or socially. Norman W. Shur's British Self-Taught, with Comments in American (1973) quotes, with obvious approval, David Abercrombie's statement:

Not only is it [Standard English] different from the dialects linguistically ... it differs from them socially and politically also. Unlike the dialects, it is not tied to any particular region of country; but is a universal form of English; it is the kind used everywhere by educated people. This, moreover, is the official form of English, the only kind which is used for public information and administration. It thus has a quite different standing in the English-speaking world from the dialects... Although it is called "English" it no longer has any necessary connection with England (1955: 101).

One could quibble about the terminology of this statement insisting, for example, that Standard English is itself a dialect, and therefore cannot be "unlike the dialects." On the whole, however, the statement is so reasonable as to disarm such criticism.

${ }^{23}$ As my discussion above implies, this statement is subject to modification in terms of the problem of just when the koiné can conveniently be said to have "begun." At any rate, the leveling process would have applied to such a first-generation child, not subject to restrictive social pressures of the kinds discussed above.

${ }^{24}$ Descriptions of Australian dialects have been given by (e.g.) A. G. Mitchell, The Pronunciation of English in Australia (1946):

There are two well-defined types of speech in Australia, an educated, cultivated professional speech, and an uncultivated popular speech (Quoted in Baker, 1945: 436).

Mitchell labeled these two "Broad Australian" and "Educated Australian." Baker himself expands the designations to

Broad Australian

General Australian

Educated Australian 
Native American reactions typically relate Australian to Cockney; it is often expressed that "An American can't tell an Australian from a Cockney." Britishers, however, find it quite easy to do so.

${ }^{25}$ John Witherspoon (quoted in Mencken, 1948: 19) associated the same processes with mobility as did Turner:

The vulgar in America speak much better than the vulgar in Great Britain, for a very obvious reason, viz,, that being much more unsettled and moving frequently from place to place, they are not so liable to local peculiarities either in accent or phraseology.

As I hope to demonstrate, this assertion-whether by Turner or by Witherspoon-is not so much wrong as irrelevant. Mobility or a "nomadic" life cannot be said to promote either uniformity or diversity, unless the circumstances of language contact in the moving about can be stated.

${ }^{26}$ Marckwardt (1958) apparently did not notice this simple chronological division. He asserted

Early travelers to America and native commentators on the language agree on the existence of regional differences at an early period in our national history. Mrs. Ann Royall called attention to various Southernisms in the works which she wrote in the second quarter of the nineteenth century, and as early as 1829, Dr. Robley Dunglison had identified many of the Americanisms, in the glossary he compiled, with particular portions of the country. Charles Dickens recognized regional differences in the English he encountered in his first tour of the United States, and William Howard Russell, reporting on Abraham Lincoln's first state banquet, at which he was a guest, mentions his astonishment at finding "a diversity of accent almost as great as if a number of foreigners had been speaking English" (1958: 131-132).

Marckwardt goes on to compare DeTocqueville's assertion that

There is no patois in the New World

Apparently, Marckwardt did not notice the fundamental time difference between these "early period" commentators. DeTocqueville wrote in the eighteenth century, whereas all the others were of the nineteenth century. The earliest of them, as a matter of fact, seems to come in the second quarter of the nineteenth century. Marckwardt was, of course, motivated by the bias of the reconstructive tradition, which wanted to see "regional" dialects represented in American English and therefore wanted to see regional differences as early as possible in the United States.

${ }^{27}$ Approximately this much of Hamilton's statement was quoted in Read's "British Recognition of American Speech in the Eighteenth Century" (1933). The further statements of Hamilton have, however, a great interest of their own. He continues

Even by this educated and respectable class, the commonest words are often so transmogrified as to be placed beyond the recognition of an Englishman. The word does is split into two syllables, and pronounced do-es. Where, for some incomprehensible reason, is converted into whare, there into thare; and I remember, on mentioning to an acquaintance that I had called on a gentleman of taste in the arts, he asked, "Whether he shew (showed) me his pictures." Such words as oratory and dilatory, are pronounced with the penult syllable, long and accented; missionary becomes missionairy; angel, angel; danger, danger \&c.

But this is not all. The Americans have chosen arbitrarily to change the meaning of certain old and established English words, for reasons which they cannot explain, and which I doubt much whether any European philologist could understand. The word clever affords a case in point. It has here no connexion with talent, and simply means pleasant or amiable. Thus, a good natured blockhead in the American vernacular, is a clever man, 
and having had this drilled into me, I foolishly imagined that all trouble with regard to this word at least, was at an end. It was not long, however, before I heard of a gentleman having moved into a clever house, of another succeeding to a clever sum of money, of a third embarking in a clever ship, and making a clever voyage, with a clever cargo; and of the sense attached to the word in these various combinations, I could gain nothing like a satisfactory explanation.

With regard to the meaning intended to be conveyed by an American in conversation, one is sometimes left utterly at large. I remember, after conversing with a very plain, but very agreeable lady, being asked whether Mrs. _ was not a very fine woman. I believe I have not more conscience than my neighbours in regard to a compliment, but in the present case there seemed something so ludicrous in the application of the term, that 1 found it really impossible to answer in the affirmative. I, therefore, ventured to hint... This led to an explanation, and I learned that, in the dialect of this country, the term fine woman refers exclusively to the intellect.

The privilege of barbarizing the King's English is assumed by all ranks and conditions of men. Such words as slick, kedge, and boss, it is true, are rarely used by the better orders; but they assume unlimited liberty in the use of "expect," "reckon," "guess," "calculate," and perpetrate conversational anomalies with the most remorseless impunity. It were easy to accumulate instances, but I will not go on with this unpleasant subject ... I feel it something of a duty to express the natural feelings of an Englishman, at finding the language of Shakespeare and Milton thus gratituitously degraded. Unless the present progress of change can be arrested, by an increase of taste and judgment in the more educated classes, there can be no doubt that, in another century, the dialect of the Americans will become utterly unin telligible to an Englishman . . (1833: 127-129).

As Charlton Laird, Language in America (1970: 457-458) points out, except for boss these words all had a prior history of use in England and therefore cannot be considered "Americanisms" in the sense that they were innovated or borrowed here. In the interpretation of this paper, they would be part of the koiné vocabulary.

${ }^{27 a}$ Marcy quoted, for example, a Texas hostess, from the dense forest region of Northwest Texas:

Wall, now, stranger, my ole man he ar out on a bar track, but I sort-o-reckon maybe you mought get to stay ... that thar war narry shaw of vittles in the house barrin some sweet taters and a small chance of corn."

"What my name mought be," "she knowed a heap of Massys (Marcy) in ole Massasip ... me an him allers "lowed that them thar Massys was considdible on bar and other varmits" (Marcy, 1866: 383).

${ }^{28}$ Specific comparisons to the European patois are sometimes made, but resemblances are regularly denied, in the travel literature:

Few of the Creole ladies [in New Orleans] can speak English, and still fewer of the slaves. The latter jabber a sort of patois unlike anything $\mathrm{I}$ ever heard in France, though my intercourse with the French peasantry has been tolerably extensive (Hamilton, 1833: 311).

For the close relationship between the speech of slaves and the ladies of the master caste (the meaning of Creole as Hamilton uses it), see my Black English, Chapter V.

${ }^{29}$ Perhaps the most familiar concerns two trappers who have been snowbound together for an entire winter. After about a month, one says "Cold weather, isn't it?" Two months later, the other answers, "If you're going to keep up that damned chatter, I'm leaving." 
${ }^{30}$ Philip Durham and Everett L. Jones, “Negro Cowboys," American West, Fall, 1964.

${ }^{31}$ For Fancy Talk, see Dillard (1972):245-257.

${ }^{32}$ Among the indications that Chinese may have played the same role in Australia that they played in American English is the following:

There is a large number of Chinamen in New South Wales [i.e., Australia], from market gardeners, cabinet makers, "fossickers," \&c to merchants (James, 1892: 290).

James also reports that restrictions had been placed on the entry of Chinese by 1892 .

${ }^{33}$ See especially Chomsky, Cartesian Linguistics (1966). Chomsky defends some of the more profoundly philosophical grammatical traditions of the seventeenth century against the charge of Latinizing the structure of modern languages (specifically French). It is still true, however, that some early grammarians of English, among them Americans, drew unwarranted conclusions about English structure (perhaps "surface structure" in current terminology) from Latin and prescribed usages in English on the basis of Latin models.

${ }^{34}$ The specific list here is taken from an older textbook, Bowyer, Beaty, Clark, and Neu, Form and Style (ca. 1940).

${ }^{35}$ As a vehicle for spreading a version of high culture to the frontier populations, the Lyceum movement provided models of "cultivated" English even for those in relatively isolated places.

The spread of the Lyceum system along the line of westward emigration from New England as far as the Mississippi is one tangible evidence of the high level of popular intelligence (Perry, 1918: 175).

${ }^{36}$ On the Chautauqua as a successor to the earlier Lyceum movement, see Edwin E. Slosson, The American Spirit in Education, Vol. 33, Chronicles of America Series, $281 \mathrm{f}$.

${ }^{37}$ For a report of a behavioral test (listerners' evaluations) which showed preference for "Network Standard" on the part of both Southern Black students in a Mississippi college and Northern (mostly white) students in a New England college, see Wallace A. Lambert and G. Richard Tucker, "White and Negro Listeners' Reactions to Various American-English Dialects," Social Forces 47, No. 4 (June, 1969) 463-468.

\section{Selected References}

\section{Abercrombie, David}

1955 Problems and Principles: Studies in the Teaching of English as a Second Language. London: Longmans, Green.

Adams, James

1799 The Pronunciation of the English Language Vindicated from Anomaly and Caprice. Edinburgh: J. Moir.

Andrews, Charles M.

1919 The Fathers of New England: A Chronicle of the Puritan Commonwealths. In Allen Johnson (ed.), The Chronicles of America, Vol. 6. New Haven: Yale University Press.

Atwood, E. Bagby

1963 "The methods of American dialectology." Zeitschrift für Mundartforschung 30 (October): 1-30. 


\section{Bailyn, Bernard}

1955 The New England Merchants in the Seventeenth Century. Cambridge: Harvard University Press.

Baker, Sidney J.

1945 The Australian Language. Sydney: Angus and Robertson.

Bernard, J. R. L. B.

1969 "On the uniformity of Australian English." Orbis 18 (No. 1): 62-73.

Blanc, Haim

1954 Communal Dialects of Baghdad Arabic. Harvard Middle Eastern Monographs, No. 10. Cambridge: Harvard University Press.

Bourke, John G.

1891 On the Border with Crook. New York: Charles Scribner's Sons.

Burton, Richard Francis

1860 The Look of the West. London.

Catlin, George

1856 Illustrations of the Manners, Customs, and Conditions of the North American Indians. Vol. II. London: H. G. Bohn.

Chomsky, Noam

1966 Cartesian Linguistics: A Chapter in the History of Rationalist Thought. New York: Harper \& Row.

Chomsky, Noam and Morris Halle

1968 The Sound Pattern of English. New York: Harper \& Row.

Coleman, William Macon

1881 The History of the Primitive Yankees; or The Pilgrim Fathers in England and Holland. Washington, D. C.: Columbia.

Creswell, Nicholas

1924 The Journal of Nicholas Creswell, 1774-1777. London: Jonathan Cape.

Davis, John

1909 Travels of Four Years and a Half in the United States of America During 1798, 1799, 1800, 1801, and 1802. New York: H. Holt.

Dick, E. N.

1941 Vanguards of the Frontier. New York: Appleton-Century.

Dillard, J. L.

1970 "Negro nonstandard dialects: convergence or divergence?" In Norman E. Whitten, Jr., and John F. Szwed (eds.), Afro-American Anthropology: Contemporary Perspectives. New York: Free Press.

1972 Black English: Its History and Usage in the United States. New York: Random House. 
Durham, Philip and Everett L. Jones

1964 "Negro cowboys." American West (Fall).

Earle, Alice Morse

1899 Child-Life in Colonial Days. London: Macmillan.

Fisher, Sydney G.

1919 The Quaker Colonies: A Chronicle of the Proprietors of the Delaware. In Allen Johnson (ed.), The Chronicles of America, Vol. 8. New Haven: Yale University Press.

Fiske, John

1889 The Beginnings of New England. Boston: Houghton Mifflin.

Francis, W. Nelson

1961 "Some dialectal verb forms in England." Orbis 10 (No. 1): 1-14.

Grose, Francis

1785 Classical Dictionary of the Vulgar Tongue. London: S. Hooper.

Gumperz, John J.

1958 "Dialect differences and social stratification in a north Indian village." American Anthropologist 60 (August): 668-682.

Hamilton, Alexander

1907 Hamilton's Itinerarium. Edited by Albert Bushnell Hart. St. Louis: W. K. Bixby.

Hamilton, Thomas

1833 Men and Manners in America. London: Blackwood.

Hills, E. C.

1929 "Linguistic substrata of American English." American Speech 4 (August): 431-433.

Hitchcock, Ethan Allen

1930 A Traveller in Indian Territory. Cedar Rapids, lowa: The Torch Press.

James, G. L.

1892 Shall I Try Australia?

Janson, Charles William

1807 Stranger in America. London: J. Cundee.

Krapp, George Philip

1925 The English Language in America. New York: Century.

Kurath, Hans

1928 "The origin of dialectal differences in spoken American English." Modern Philology 25 (May). 
1936 "The linguistic atlas of the United States and Canada." In D. B. Fry and Daniel Jones (eds.), Proceedings of the Second International Conference of Phonetic Sciences. Cambridge, England: University Press.

1971 "Some aspects of Atlantic-seabord English considered in their connection with British English." Pp. 101-107 in Juanita V. Williamson and Virginia M. Burke (eds.), A Various Language: Perspectives on American Dialects. New York: Holt, Rinehart and Winston.

Labov, William

1966 The Social Stratification of English in New York City. Washington, D. C.: Center for Applied Linguistics.

1972a Language in the Inner City: Studies in the Black Vernacular. Philadelphia: University of Pennsylvania Press.

1972bSociolinguistic Patterns. Philadelphia: University of Pennsylvania Press.

1973 "The linguistic consequences of being a lame." Language in Society 2.

Laird, Charlton Grant

1970 Language in America. New York: World.

Lambert, Wallace A. and G. Richard Tucker

1969 "White and Negro listeners' reactions to various American-English dialects." Social Forces 47 (June): $463-468$.

Leechman, Douglas and Robert A. Hall, Jr.

1955 "American Indian pidgin English: attestations and grammatical peculiarities." American Speech 30 (October): 163-171.

Leopold, Warner F.

1959 "The decline of German dialects." Word 15 (April): 130-153.

Marckwardt, Albert $\mathrm{H}$.

1958 American English. New York: Oxford University Press.

Marcy, Randolph Barnes

1866 Thirty Years of Army Life on the Border. New York: Harper.

Maryland Historical Magazine

1916 "Letters of Rev. Jonathan Boucher." 10.

Mason, Julian

1960 "The etymology of buckaroo." American Speech 35 (February) : 51-55.

McDavid, Raven I., Jr.

1967 "Historical, regional, and social variation," Journal of English Linguistics 1.

Mead, Margaret

1956 New Lives for Old: Cultural Transformation-Manus, 1928-1953. New York: Morrow. 
Mencken, H. L.

1945 The American Language. Supplement I. New York: Alfred A. Knopf.

1948 The American Language. Supplement II. New York: Alfred A. Knopf.

Miller; Mary Rita

1967 "Attestations of American Indian pidgin English in fiction and nonfiction." American Speech 42.

Mitchell, A. G.

1946 The Pronunciation of English in Australia. Sydney: Angus and Robertson.

Orbeck, Anders

1927 Early New England Pronunciation. Ann Arbor, Michigan: G. Wahr.

Paullin, Charles O. and John D. Wright

1932 Atlas of the Historical Geography of the United States. Washington, D. C.: Carnegie Institution.

Perry, Bliss

1918 The American Spirit in Literature: A Chronicle of Great Interpreters. In Allen Johnson (ed.), The Chronicles of America, Vol. 34. New Haven: Yale University Press.

Plooij, Daniël

1932 The Pilgrim Fathers from a Dutch Point of View. New York: The New York University Press.

Read, Allen Walker

1933 "British recognition of American speech in the eighteenth century." Dialect Notes 6 (Part 6): 313-334.

1938 "The assimilation of the speech of British immigrants in colonial America." Journal of English and Germanic Philology 37 (January): 70-79.

Richardson, Albert D.

1867 Beyond the Mississippi. New York: Bliss.

Rusling, James $F$.

1875 Across America. New York: Sheldon.

Schur, Norman W.

1973 British Self-Taught, with Comments in American. New York: Macmillan.

Slosson, Edwin E.

1921 The American Spirit in Education: A Chronicle of Great Teachers. In Allen Johnson (ed.), The Chronicles of America, Vol. 33. New Haven: Yale University Press.

Smyth, J. F. D.

1784 A Tour of the United States of America. 2 vols. London: G. Robinson.

Stewart, William A.

1967 "Sociolinguistic factors in the history of American Negro dialects." Florida Foreign Language Reporter 5: 11-29. 
1968 "Continuity and change in American Negro dialects." Florida Foreign Language Reporter 6: 3-14.

Turner, G. W.

1966 The English Language in Australia and New Zealand. London: Longmans.

Williamson, Juanita V. and Virginia M. Burke (eds.)

1971 A Various Language: Perspectives on American Dialects. New York: Holt, Rinehart and Winston.

Woodward, Thomas Simpson

1859 Woodward's Reminiscences of the Creek or Muscogee Indians. Montgomery, Alabama: Berrett \& Wimbish.

Wright, Joseph

1964 English Dialect Dictionary. London: Oxford University Press. 